\title{
Insect feeds in salmon aquaculture: sociotechnical imagination and responsible story-telling
}

\author{
R. Strand ${ }^{1 *}\left(\mathrm{D}\right.$, G. Gamboa ${ }^{2}$, D.J. Dankel ${ }^{1,3}$ and M. Giampietro ${ }^{2,4}$ \\ ${ }^{1}$ Centre for the Study of the Sciences and the Humanities, University of Bergen, P.O. Box 7805, Bergen, 5020, Norway; \\ ${ }^{2}$ Institut de Ciència $i$ Tecnologia Ambientals, Universitat Autònoma de Barcelona, Bellaterra, 08193, Spain; ${ }^{3}$ Department \\ of Biological Sciences, University of Bergen, Thormøhlensgt 53B, Bergen, 5020, Norway; ${ }^{4}$ Institució Catalana de Recerca $i$ \\ Estudis Avançats (ICREA), Barcelona, 08010, Spain; roger.strand@uib.no; rogstra3@gmail.com
}

Received: 1 October 2020 / Accepted: 24 June 2021

(c) 2021 Wageningen Academic Publishers

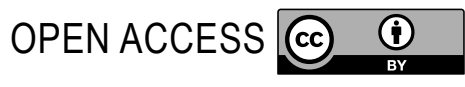

RESEARCH ARTICLE

\begin{abstract}
Salmon aquaculture is a growing industry with increasing challenges of feed sustainability and availability. This global sustainability issue has led to calls for novel feeds. Aquafly, a Norwegian research project, has performed small-scale tests using the black soldier fly as an ingredient in salmon diet. However, in order for insect feeds to become a reality on the industrial scale, workable scientific, technical and political solutions have to be envisioned in tandem. In this study, we studied, elicited and assessed sociotechnical imaginaries in the Aquafly research consortium, using the approaches of concomitant ELSA research, the Ethical Matrix and Quantitative Story-Telling. We show how the sociotechnical imaginaries develop together with the scientific trajectory of the project, and how this also affects the assessment of the ethical and environmental impacts of the technology, including issues of food and feed safety and security, fish health and welfare, pollution and efficient use of waste streams. We show how there are intrinsic challenges when dealing with global sustainability issues in the research project. For instance, overcoming the problem of salmon feed scarcity may aggravate the challenges caused by intensive aquaculture. We report the results of a Quantitative Story-Telling exercise that indicates that Aquafly can be seen as part of a larger economy of technological promise, and discuss if and how this critique can be employed and integrated into scientific and technical imagination in a research project, contributing to Responsible Research and Innovation.
\end{abstract}

Keywords: responsible research and innovation, RRI, quantitative story-telling, ethical matrix, anticipation, sustainable development goals

\section{Introduction}

Currently, aquaculture supplies about half of the total consumption of seafood for human consumption, and while global captures have remained almost constant since the 1980s, aquaculture production has grown at annual rates about $10 \%$ in the 80 s and above $5 \%$ currently (FAO, 2018).

Global fish consumption has increased from $12 \mathrm{~kg} /$ capita in 1980 to abut $20 \mathrm{~kg} / \mathrm{capita}$ in 2015 . This increase in fish consumption parallel to population growth has been possible thanks to the rapid growth of the aquaculture industry. Aquaculture is expected to play a key role in supplying seafood in the future, and considering these trends, it becomes an imperative to find substitutes of fish meal (FM) and fish oil (FO) in feed composition to make feed provision more sustainable and reliable (Gasco et al., 2018). Novel feeds are being proposed as (part) solutions. For instance, insects have received increasing attention and interest as protein source for animal feed production (FAO, 2013; Makkar et al., 2014), as have yeasts and bacteria.

The requirements for novel feeds are multiple and by no means trivial. Feed has to be safe and healthy for fish and humans; be accessible and available from a large-scale sustainable supplier at a competitive price; perform well in terms of nutrient content, digestibility and palatability for the fish, and perform well in terms of sensory 
properties (taste, odour, colour and texture) of the fish for the consumers. For instance, chemical composition and nutritional value of insect larvae depends on the larvae rearing substrate and on processing methods (Henry et al., 2015) which also affects the utilisation of the larvae by fish (Makkar et al., 2014). In addition, there may be logistic, regulatory, ethical and social concerns and challenges.

Insects are, of course, food for wild salmon. Still, production of massive amounts of insects for salmon aquaculture is new territory for the industry as well as aquaculture research and technology development. There are technical challenges but also substantial knowledge gaps.

The present study followed and interacted with a publicly funded research project, 'Aquafly: Insects as natural feed ingredients for sustainable salmon farming' (hereafter: Aquafly), from the conception of its idea in 2014, through project funding and formal onset in 2015 and until 2018. Aquafly was conceived and coordinated by the National Institute of Nutrition and Seafood Research in Norway (which was later merged with the Institute of Marine Research in Norway) and obtained a public funding of 13.3 mill NOK in addition to in-kind contributions, shared between the coordinator and several national and international academic partners. The consortium also included Protix, a Dutch company specialising in the production of black soldier fly at industrial scales. Finally, the authors of this study were partners of Aquafly, with the assigned task of performing real time ethical and environmental technology assessments during the project.

As we had expected, the assessment exercise proved to be difficult because its object - the insect feed and the technological solution for its large-scale production - was neither a well-defined nor a fixed entity. Rather, it was, and still is, a continuously moving target. Fluidity, tentativeness and open-endedness is characteristic of much scientific research (Pickering, 1995), and not the least when science is given the task of creating a novel technological solution to a complex problem. In principle, the Aquafly project had an indefinite number of degrees of freedom in its search for the right insect, the right feed for the insect, the right conditions for rearing the insects, the appropriate sources for the insects and insect feeds, et cetera; 'everything' was possible. On the other hand, as noted above, the constraints on the solution to be sought were equally numerous, in terms of health, safety, sustainability, economics, ethics and politics. The task that Aquafly had taken on was to unfold a research trajectory that, within the myriad of thinkable technological solutions, had a reasonable chance of discovering a solution that fit the requirements.

The French sociologist Bruno Latour famously distinguished between 'ready-made science' and 'science-in-the-making' (Latour, 1987). When a technological solution has been provided, it appears as 'ready-made', as a fact and as a given. One may then proceed to assess its qualities, for instance in terms of the environmental impacts it creates or the ethical issues that it poses. Such assessments may be useful for decisions on how to regulate the technology. In principle, the assessment could also be used to decide for or against its implementation. In practice, however, a technology that promises profit for its inventor or some other stakeholder, tends to create its own push into implementation. Undesirable ethical, social or environmental impacts may be hard to predict and even harder to prove ex ante. When they finally become evident, it may be too late, in the sense that the harm has already occurred or that the technology has become entrenched in infrastructure, society or culture. This essential problem of technology assessment is sometimes referred to as the 'Collingridge dilemma' (Collingridge, 1980). Accordingly, technology assessment in its many forms has increasingly come to direct more attention towards science-in-the-making to look for opportunities to shape research and development trajectories in ethically and environmentally desirable ways. There are a number of labels for these attempts: upstream engagement and precautionary approaches (Wynne, 1992), constructive technology assessment, (Rip, 2018) real-time technology assessment, ongoing normative assessment (Grinbaum and Dupuy, 2004), and, of late, responsible research and innovation ('RRI'; see Von Schomberg, 2011).

Four process dimensions have been emphasised in the literature on RRI and its synonym Responsible Innovation (Stilgoe et al., 2013): anticipation, reflexivity, (public) engagement and responsiveness. In order to take responsibility for the ethical, social and environmental desirability of a scientific or technological product, the researchers are expected to make an effort to anticipate the impacts of its use and implementation, reflect on their significance, engage with broader groups of citizens and stakeholders and learn from their needs and concerns, and 'respond', that is, adjust the research trajectory in accordance with what has been learnt. In Aquafly, the ethical and environmental assessment exercise mainly corresponded to the process dimensions of anticipation and reflexivity. Two assessment approaches - the Ethical Matrix and Quantitative Story-Telling, to be introduced below were applied not to produce 'the Truth' about a ready-made technology, but as a way to interact with the creative and imaginative research process in the search for a workable solution to insect feeds to salmon. We elicited, introduced and facilitated reflection upon ethical and environmental concerns in order for these concerns to play a role in the creative research process.

'Responsiveness', or the translation of ethical and environmental concerns, remains a hope and perhaps somewhat of a wishful thought in the literature on RRI. It is not always obvious how such concerns can be 
accommodated by changes in research design, in particular when the technological readiness in question is somewhat lacking, as in the Aquafly project, which aimed at nothing more than a proof of principle. It is important to realise, however, that researchers and technology developers deliver more than the actual material technology. Sheila Jasanoff and colleagues (Jasanoff and Kim, 2009) have demonstrated how the practices of designing, funding and executing research should be understood as a simultaneous 'coproduction of science, technology and society'. In order for research to be funded and carried out, in the midst of all of the tentativeness and degrees of freedom, there need to be visions that give direction to the work. These visions have been called 'sociotechnical imaginaries', and they can be understood as visions of a future desirable and obtainable state of (simultaneously) scientific, technological and social order. While this dynamic easily may escalate to what has been called the sociology of expectation and economies of hope and unjustified promises, Jasanoff has emphasised that the creation of sociotechnical imaginaries are part of the normal workings of research funding and research practices, perhaps even a necessary part.

To make it more concrete, the Aquafly research proposal envisioned a desirable future in which salmon aquaculture could rely on sustainable supplies of insects that in their term had been fed with novel or under-used marine organic matters. This could increase salmon production, increase environmental sustainability and still maintain the omega-3 fatty acid levels that are thought to make farmed salmon a healthy food. The proposal also described the scientific knowledge required to reach this future state, and promised to undertake it.

The point here is that a research proposal does much more than just scientific work. It also imagines (explicitly or inexplicity) social goals and trajectories towards them. In exactly this sense, scientific research performs what has been called 'de facto politics': it makes decisions that have a strong bearing on the future of our society (and environment). When this aspect of scientific research is acknowledged, however, new opportunities open up for responsiveness as an RRI dimension within the project. Even if it is difficult to argue for changes in research trajectories upon the anticipation and reflection during a real-time technology assessment, it can contribute to the shaping of the corresponding sociotechnical imaginaries. these imanginaries may then inform the many technical and social choices to be made downstream of a project such as Aquafly, from the proof of principle to possible implementation, upscaling and the imagination and materialisation of everything from production facilities and transport infrastructures to regulatory measures. While we will explain the two chosen approaches in full below, our main objectives were to (1) elicit and document imaginaries, objectives and concerns already present in the research consortium by concomitant research and the use of the Ethical Matrix and (2) use the Ethical Matrix results to examine and pursue possible contradictions by the use of QST. We will describe these approaches in some more detail before turning to our results.

\section{Concepts and methods}

\section{Accompanying research ('Begleitvorschung')}

This study is a case of concomitant or accompanying research, what in German is called Begleitvorschung, and similar to what has been called 'ELSA research' - research on the ethical, legal and social aspects of technological or technoscientific research. As such it was a part of the Aquafly project itself, but organised in its own work package and with its own budget. Furthermore, it was a design choice of the Aquafly coordinator that the ethical and environmental assessment should be undertaken by research partners who belonged to other research organisations and were not directly involved in the technical work. This was intended to secure a certain autonomy.

As accompanying researchers, we attended Aquafly project meetings and had continuous access to project results. We presented at project meetings and led discussions, maintained correspondence with Aquafly researchers and had one-to-one meetings with the Aquafly PI. For the construction of the ethical matrices, we organised two workshops with the project participants and their colleagues (in addition to a preliminary workshop with researchers at an international conference for research on insects as food and feed).

\section{The ethical matrix approach}

The ethical matrix approach was developed to organise the elicitation and deliberation of ethical concerns in complex cases, and has been used several times also for contested issues around aquaculture (Bremer et al., 2015; Kaiser and Forsberg, 2001). The approach has two key elements: deliberation in a workshop format and the so-called ethical matrices that are kept in focus during the discussions. The ethical matrix in its most general form consists of rows that list selected moral objects, that is, 'entities to care for', and columns with selected ethical principles to be considered and respected in the deliberation. Participants were asked to fill in, orally or in writing, their ideas for the various squares of the matrix. Next, during workshops, the discussion systematically turned from square to square, the moderator taking notes. In this case, the process included a set of three matrices, based on the moderator's notes and the matrices that each individual filled in.

First, the general matrix was constructed for each workshop, listing generally relevant ethical issues in aquaculture. Next, 
a specific ethical concern matrix was constructed, listing the issues that were considered as relevant in the context of the Aquafly project. Finally, an ethical and environmental impact matrix was constructed, in which the columns listed future scenarios relevant for Aquafly and the squares expressed the expected impact of each option with regard to the entity and the ethical concern in question. The set of scenarios for the impact matrix was chosen by the Aquafly PI after a lengthy process of deliberation.

The general ethical matrix was designed by us, on the basis of previous research (Bremer et al., 2015; Kaiser and Forsberg, 2001) and consultation with the first authors of those studies. In the two workshops, the general ethical matrix was presented together with a draft of the ethical concerns matrix (based on project meetings, consultations and the preliminary workshop), and a blank impact matrix. The participants were then led by a moderator (Strand) to critically discuss and revise each matrix and provide input for the impact matrix. Two workshops were organised to include researchers in two Norwegian cities.

The general ethical matrix, presented to workshop participants, was designed as follows in Table 1. The design largely followed previous usage of the ethical matrix for issues in aquaculture. The 'entities to care for' were identified by following the value chain of salmon farming and imagining affected parties along that chain. The choice of ethical principles also followed common practice and was initially inspired by the four principles of biomedical ethics formulated by Beauchamp and Childress (1979). In some cases their application calls for significant interpretational flexibility, as when asking what autonomy means for animals. The resulting imprecision does not create much of a problem for an Ethical Matrix exercise, however, because the columns are not weighed against each other but function as additional, complementary and partly overlapping occasions to elicit ethical issues and concerns. The explanation of the principles to the workshop participants is provided in a footnote. ${ }^{1}$

\section{Quantitative story-telling}

Quantitative Story-Telling (QST) proposes a new way of using scientific analysis in the process of decision making. QST is an alternative to the concept of 'evidence based policy' assuming that specific pieces of information can be used as 'evidence' to inform policy-makers (Saltelli and Giampietro, 2017). While the latter aims at identifying the 'best course of action' using models, QST anticipates possible troubles associated with proposed policies by carrying out an extended 'quality check on the production

\footnotetext{
1 'Beneficence' is related to utility and the ethical value of increased benefit in terms of utility, health, welfare, happiness, etc. It is similar to 'benefit' in cost-benefit analysis. 'Non-maleficence' is related to the ethical value of reducing harm to health, welfare, happiness, etc. It can be thought of as similar to 'cost' but also to risk. The right to 'autonomy' is a key ethical principle for humans. Human persons have the moral right to self-determination through their own, autonomous decisions. For non-human entities such as animals and ecosystems, 'respect for autonomy' in the ethical matrix is better interpreted as the respect for others (animals or ecosystems) as ends in themselves. In a similar fashion it can be interpreted as respect for others' identity - that they are what or who they are - as well as their 'dignity'. Respect for 'justice as fairness' is easily understood for humans. For non-humans, fairness can be treated in various ways. For instance, for biota, fairness can be conceived as their sustainability. For animals, justice as fairness can be a matter of respecting their intrinsic value, which we may interpret as their intrinsic right to existence. 'Fairness' does not entail that this right is absolute; on the other hand, it is not void. Philosophical analysis indicates, and practical examples show, that it is not easy to distinguish exactly what should count as autonomy and what as fairness for non-human entities. That is not a big problem since the matrix is merely used to get an overview and is not intended (or suitable) for arithmetic operations.
}

Table 1. General Ethical Matrix.

\begin{tabular}{|c|c|c|c|c|}
\hline \multirow[t]{2}{*}{ Entities to care for } & \multicolumn{4}{|c|}{ Respect for 4 ethical principles } \\
\hline & Beneficence & Non-maleficence & Autonomy & Justice as fairness \\
\hline \multicolumn{5}{|l|}{ Animals } \\
\hline \multicolumn{5}{|l|}{ Producers } \\
\hline \multicolumn{5}{|l|}{ Industry } \\
\hline \multicolumn{5}{|l|}{ Retailers } \\
\hline \multicolumn{5}{|l|}{ Consumers } \\
\hline Environment & & & & \\
\hline
\end{tabular}


and use of narratives' (rather than models) in the process of decision making. The ultimate goal is to check the robustness of knowledge claims in face of uncertainty. QST focuses its quality check on the usefulness and the pertinence of the pre-analytical choice of narratives behind a given issue definition (semantic framing) that are reflected later on in the consequent problem structuring (formal framing). Therefore, QST is a heuristic approach aimed at providing a quality control on the process used to 'structure both the specific perception (qualitative) and representation (quantitative) of a given issue relevant for policy making'. The difference between evidence based policy and QST can be explained with the metaphor of the thinking outside the box. Whereas the evidence produced by models is generated within a given 'box' determined by the preanalytical choice of a relevant narrative about the issue to be dealt with, the analysis provided by QST is about comparing the usefulness of different epistemic boxes that can be used to perceive and represent a specific issue of interest. More specifically, when dealing with the production and use of quantitative information to be used for governance QST makes it possible to identify and discuss the preanalytical choices of two different types of narratives: (1) a justification narrative - WHY should we do something which is behind the choice of a given policy; (2) a normative narrative - WHAT should be done - which is represented by the policy itself. On the contrary, evidence based models refer only to the explanatory narrative - HOW to do WHAT has been identified in the selected normative narrative. For this reason the quality of the choice of the WHY and the WHAT, that has been done in a pre-analytica phase, cannot be checked by using formal models or by adopting the wisdom of disciplinary knowledge - i.e. the axioms of economics, ecology, engineering, sociology. Disciplinary knowledge assumes by default that the narrative within which the disciplinary analysis is carried out (the WHYWHAT relation) is valid, pertinent and useful for dealing with the proposed issue. Disciplinary knowledge can only provide useful information about the HOW required for a given WHAT. For this reason, QST must be by default transdisciplinary. One should be able to discuss and agree on the relevant features of the performance of the system we want to monitor, control or change before deciding which disciplines should be used to frame an issue in scientific terms. How can the aspects of concern should be observed and studied? What is the expected set of relations to be associated with the concept of performance? In relation to this point, QST can be used to check whether what is proposed is: (1) feasible (compatible with external constraints determined by processes outside human control); (2) viable (compatible with internal constraints determined by processes under human control); and (3) desirable (compatible with normative values shared by social actors and guaranteeing the cohesion of the social fabric).
In this paper, we illustrate an example of the possible use of QST to enhance the reflexivity and the anticipation of the involved actors in relation to the consequences of decisions referring to a specific issue of interest (producing salmons with new types of feed). This case study presents a situation in which we do not even have a reliable definition of the options to be considered to assess the feasibility and viability of a at large scale implementation of insect-based feed production. Rather than being a problem for QST, this case study illustrates the flexibility of this approach. Rather than considering specific instances of future scenarios (what would be done by conventional models) QST makes it possible to characterise in general terms the FEASIBILITY and VIABILITY of sociotechnical imaginaries checking whether we are discussing of genuine options or just of unfeasible and unviable fantasies. The quality check has been structured on the ethical concerns with respect to salmon feeding alternatives based on insect larvae identified by the researchers themselves, in workshops using the Ethical Matrix approach. Some of these concerns were then translated into attributes and indicators, which were used to assess the feasibility and viability of the feeding models in biophysical terms, using the approach of multi-scale integrated analysis of societal and ecosystem metabolism (MuSIASEM) on selected aspects. It should be noted that QST does not have the goal to provide the 'truth' about insect feeds for salmon aquaculture to the social actor deliberating about policies. QST does not identify 'the best course of action. Rather it is intended to broaden the scope of the discussion to expand the narratives, perspectives and values that should be considered as relevant when deliberating over a specific policy. In this way, it becomes possible to reflect on the fact that the imagined social and technical goals (= imaginaries) shape the research trajectory that in turn re-shapes the imaginaries.

The quantitative framework used for QST - the MuSIASEM approach - makes it possible to tailor quantitative analysis (the crunching of numbers) on the different choices of narratives used to frame the issue identified as relevant in the process of QST. What scientific disciplines should be considered to get relevant information in relation to a specific concern? What are the relevant features of the performance of the system we want to monitor, control or change? What is the level of uncertainty that we should consider in relation to the various types of analysis proposed? How can these factors be observed and studied? Are we happy with the chosen definition of performance?

In relation to this point, QST represents a radical change in the strategy of use of scientific information for governance. In fact, it abandons the 'Cartesian dream of prediction and control' (Pereira and Funtowicz, 2015) that seeks the use of models and quantitative indicator to individuate 'optimal solutions' (optimising or minimising functions), assuming that the information used in the process of deliberation 
(pre-analytical choice of narrative, choice of models and data) is pertinent and reliable 'by default'. Rather QST uses quantitative analysis to improve the robustness of the information used in the process of deliberation: quantitative information is used to test the (biophysical) feasibility and/ or (economic and political) viability of the narratives that are assumed to be valid at the moment to propose policies. This happens when a quantitative analysis carried out within a given narrative - e.g. we can collect, with very high economic costs, only $1 \mathrm{~kg}$ of used cooking oil per capita per person per year - provides results that are incompatible with the story told by another narrative - e.g. biodiesel based on used cooking oil represent a viable alternative to traditional diesel consumption in Europe (which is around $500 \mathrm{~kg}$ per capita per year). QST avoids 'the trap of 'solving' the complexity associated with our interaction with the external world by simplification' associated with the development of quantitative models based on the choice of a single narrative, a single scale, and a single dimension at the time. Rather, it proposes a strategy based on the simultaneous generation of different assessments referring to different scales and dimensions of analysis which are relevant for checking the feasibility, viability and desirability considering the existence of legitimate and non-equivalent perceptions of performance of different relevant actors.

\section{Results}

\section{The development of research trajectory and the sociotechnical imaginaries of AquaFly}

As part of our concomitant research, we documented the research trajectory and imaginaries of Aquafly as a collaborative research project.

The Aquafly research proposal primarily directed itself towards the shortage of marine feed ingredients in salmon aquaculture. It posed the research hypothesis that insects could be used to 'upgrade' marine resources not fit for human consumption (kelp, tunicates and possibly waste from fishing and aquaculture) and convert them into high quality nutrients for salmon. Thereby Aquafly offered a vision of a possibly sustainable supply of feeds that would keep the desired 'marine' nutritional qualities of the salmon, notably the high content of omega-3 fatty acids, while avoiding high levels of marine pollutants such as arsenic and mercury. The research proposal also offered the scientific programme of action corresponding to this imaginary: A research project that would provide proof of principle for production of insects fed on kelp and tunicates and that would document the transfer of nutrients from marine materials to insects and then to salmon, as well as a study of the food safety aspects regarding the transfer of contaminants and pathogens. The two suggested insect species were the kelp fly (Coelopa frigida), a native Norwegian species known to feed on kelp, and the black soldier fly (Hermetia illucens), which has the ability to grow well in organic waste and produce high-quality protein and fat (Belghit et al., 2019; Diener et al., 2009, 2011; Makkar et al., 2014) and for which there already was an industrialscale producer, namely Protix.

As one could expect, some of the imagined technical possibilities proved hard to realise. At project half-time, the kelp fly was abandoned as it proved too difficult to rear in the amounts needed even for a small-scale feeding experiment. The project hence focused exclusively on the black soldier fly, which proved able to be included in salmon feed without compromising feed safety or nutritional value (Belghit et al., 2019; Liland et al., 2017). The black soldier fly also proved able to digest kelp and accumulate marine fatty acids, though not in the amounts hoped for. The larvae showed poor growth when fed too much kelp (Liland et al., 2017).

The failure with the kelp fly, the somewhat suboptimal growth of black soldier fly on kelp and concerns about the environmental sustainability and economic viability of harvesting kelp in the amounts needed for salmon farming led to the original 'novel marine resource' imaginary of Aquafly being played down, resulting in a technical shift towards (insect) meal rather than the prospects of insect oil being able to alleviate the demand for fish oil in salmon aquaculture. Furthermore, the experiments with tunicates also proved technically difficult. In the same period, the imaginaries of the circular economy entered the stage of European Union policy debates, with a focus on the opportunities of better exploiting various sources of waste products, including from agriculture and plant-based food industry. This shift in the definition of the identity of the 'supply system' of feed - from 'insects feeding on kelp', to 'insects feeding on wastes' - totally changes the set of story-tellings that should be considered in order to generate an acceptable level of both reflexivity and anticipation in a deliberation based on the possible consequences of a large scale production of this new supply system. This would require a new process of analysis of ethical concerns and QST based on a different set of quantitative indicators of feasibility and viability.

In sum, Aquafly is a telling case of how a scientific research project is also a site of social imagination. The research proposal created a vision of a good, sustainable future in which edible fish no longer is used to make marine oils to be fed to salmon in order to secure omega-3 content. As a consequence of the results of the laboratory experiments and the simultaneous changes in the European policy environment, the imaginary partially changed into one of a good, sustainable future in which waste streams can be led into salmon via insects to make their energy and bulk macronutrients available for human consumption. 
Whether 'we', the authors of this study and the ones carrying out the ethical and environmental assessment exercises, had any impact on the development of the research trajectory and the sociotechnical imaginaries of the project, cannot be precisely assessed by us. Our qualified guess is that our direct impact on specific project decisions may have been small within the time-scale of the project, which ended in 2018. Rather, the anticipation and assessment exercises may have worked to trigger reflexivity, in particular on broader issues involved in the further development of sociotechnical imaginaries of the Aquafly researchers and partners, who continue their activity in other projects.

\section{Ethical matrix workshops}

The first step was to discuss and revise the general ethical matrix for salmon aquaculture as suggested by the moderator. This matrix should be understood as a compilation of ethical issues in general, not merely the ones at stake in Aquafly. Table 2 shows the aggregated results. As is evident, the workshop deliberation added several rows to the matrix.

The next step was to connected concrete questions, worries, problems, challenges and opportunities in AquaFly to the

Table 2. General Ethical Matrix for AquaFly.

\begin{tabular}{|c|c|c|c|c|}
\hline \multirow[t]{2}{*}{ Entities to care for } & \multicolumn{4}{|l|}{ Respect for 4 ethical principles } \\
\hline & Beneficence & Non-maleficence & Autonomy & Justice as fairness \\
\hline Animals (Salmon; insects) & $\begin{array}{l}\text { Animal welfare: health, } \\
\text { nutrition, appetite }\end{array}$ & $\begin{array}{l}\text { Animal welfare: health, } \\
\text { nutrition, appetite; feed safety }\end{array}$ & $\begin{array}{l}\text { Freedom of movement and } \\
\text { natural eating behaviours; } \\
\text { freedom to propagate }\end{array}$ & $\begin{array}{l}\text { Respect for its intrinsic value; } \\
\text { respect for the individual }\end{array}$ \\
\hline Producers & $\begin{array}{l}\text { Profit, working conditions; } \\
\text { moral satisfaction }\end{array}$ & $\begin{array}{l}\text { Dependency on natural } \\
\text { resources and supplies; } \\
\text { occupational risks, safety }\end{array}$ & $\begin{array}{l}\text { Freedom to choose } \\
\text { technology and ways of } \\
\text { operation }\end{array}$ & Fair trade conditions \\
\hline Industry & Profit; moral satisfaction & $\begin{array}{l}\text { Dependency on natural } \\
\text { resources and supplies; food } \\
\text { scandals, negative publicity }{ }^{1}\end{array}$ & $\begin{array}{l}\text { Freedom to choose } \\
\text { technology and ways of } \\
\text { operation; freedom to choose } \\
\text { their market message }\end{array}$ & Fair trade conditions \\
\hline Retailers & $\begin{array}{l}\text { Profit; moral satisfaction; } \\
\text { product diversification }\end{array}$ & $\begin{array}{l}\text { Food scandals, negative } \\
\text { publicity }\end{array}$ & $\begin{array}{l}\text { Having the choice to include } \\
\text { or not }\end{array}$ & Fair trade conditions \\
\hline Consumers & $\begin{array}{l}\text { Access to nutritious, tasty and } \\
\text { culturally appropriate food; } \\
\text { health benefits of food; the } \\
\text { sensation of doing something } \\
\text { good for the environment }\end{array}$ & $\begin{array}{l}\text { Food safety; YUCK factor } \\
\text { experiences, experience of } \\
\text { distrust in food safety }\end{array}$ & $\begin{array}{l}\text { Consumer choice, product } \\
\text { information; respect for } \\
\text { culinary traditions; possibility } \\
\text { to choose more sustainable } \\
\text { alternative }\end{array}$ & $\begin{array}{l}\text { Availability and affordance } \\
\text { of the food; national food } \\
\text { sovereignty and food security }\end{array}$ \\
\hline $\begin{array}{l}\text { Environment } \\
\text { (fjord, kelp by netpen) }\end{array}$ & Preservation & Pollution & Biological diversity & Sustainability \\
\hline $\begin{array}{l}\text { Environment } \\
\text { (marine ecosystem, kelp, fish } \\
\text { for feed) }\end{array}$ & Preservation & Over-exploitation & Biological diversity & Sustainability \\
\hline $\begin{array}{l}\text { Environment } \\
\text { (local terrestrial socio- } \\
\text { ecological systems) }\end{array}$ & $\begin{array}{l}\text { Preservation; better use of } \\
\text { resources and waste streams }\end{array}$ & $\begin{array}{l}\text { Pollution, risks of insect } \\
\text { escapes }\end{array}$ & Biological diversity & Sustainability \\
\hline $\begin{array}{l}\text { Environment } \\
\text { (global) }\end{array}$ & Preservation & Over-exploitation & Biological diversity & $\begin{array}{l}\text { Sustainability but also fair } \\
\text { distribution of scarce feed } \\
\text { resources, especially in the } \\
\text { future }\end{array}$ \\
\hline Local community & Jobs, value creation & $\begin{array}{l}\text { Conflicts with other industries, } \\
\text { area conflicts, pollution, } \\
\text { competition over feed } \\
\text { resources }\end{array}$ & $\begin{array}{l}\text { The reputation of the } \\
\text { community }\end{array}$ & $\begin{array}{l}\text { Fair handling by authorities } \\
\text { (taxation and distribution of } \\
\text { value creation) }\end{array}$ \\
\hline Society, national level & $\begin{array}{l}\text { Jobs, value creation, proper } \\
\text { exploitation of biological } \\
\text { resources }\end{array}$ & $\begin{array}{l}\text { Environmental risks, market } \\
\text { risks }\end{array}$ & & \\
\hline
\end{tabular}

\footnotetext{
${ }^{1}$ Reputation risks were seen as important because salmon is a product in a high-end market. One participant expressed the following: 'The industry fears to introduce differentiation of salmon products according to differentiated feed. In the moment one does that, one admits that one type of feed is better than another. This may pose a reputation risk to the entire industry and the nation.'
} 
entries in the General Ethical Matrix to produce the Ethical Concerns Matrix. Table 3 shows the aggregated results.

It should be added that quite a lot of the discussion during the workshops did not fit well into one unique square of the matrices but dealt with the interdependencies, especially the dynamic relationships between feed availabilities and where to use that feed. For instance, if insects become an important ingredient for salmon feed, what should the insects be fed? At the time of the workshops, kelp (a marine macroalgae) was not considered a realistic alternative anymore. If the solution was going to be to feed

Table 3. Ethical concerns matrix for Aquafly.

\begin{tabular}{|c|c|c|c|c|}
\hline \multirow[t]{2}{*}{ Entities to care for } & \multicolumn{4}{|l|}{ Respect for 4 ethical principles } \\
\hline & Beneficence & Non-maleficence & Autonomy & Justice as fairness \\
\hline Animals & $\begin{array}{l}\text { Will the salmon enjoy the } \\
\text { insect feed more or less than } \\
\text { standard feed? Fish health: } \\
\text { Will it become a healthier } \\
\text { salmon? The hypothesis is } \\
\text { that insect feed should create } \\
\text { a more healthy salmom } \\
\text { because it will eat more chitin. }\end{array}$ & $\begin{array}{l}\text { Is the insect feed safe for } \\
\text { the salmon? Are there risks } \\
\text { of malnutrition or disease } \\
\text { (zoonosis)? Insect feeds } \\
\text { have unknown chemistries. } \\
\text { There may be pollutants but } \\
\text { also poorly known signal } \\
\text { molecules that pose feed } \\
\text { safety risks. } \\
\text { Do the insects experience } \\
\text { a lot of stress? Excess } \\
\text { handling? Starvation? }\end{array}$ & $\begin{array}{l}\text { Do salmon prefer the novel } \\
\text { feed over conventional feeds? } \\
\text { Is it more natural? } \\
\text { Will the salmon be allowed to } \\
\text { choose feed? } \\
\text { What kind of mating } \\
\text { conditions do the flies have? } \\
\text { Are black soldier flies going to } \\
\text { be grown in Norway? (Foreign } \\
\text { species) }\end{array}$ & $\begin{array}{l}\text { Wild salmon actually eats } \\
\text { insects; insect feeds could be } \\
\text { said to be more 'natural'. } \\
\text { Should we treat the flies as } \\
\text { individuals? }\end{array}$ \\
\hline Producers & $\begin{array}{l}\text { The effect of insect feeds } \\
\text { on profitability and on work } \\
\text { operations. }\end{array}$ & $\begin{array}{l}\text { Will feed supplies become } \\
\text { more robust? }\end{array}$ & $\begin{array}{l}\text { Would Norwegian producers } \\
\text { be less dependent on multi- } \\
\text { national feed corporations? }\end{array}$ & $\begin{array}{l}\text { Will insect feeds be allowed } \\
\text { by regulation? }\end{array}$ \\
\hline Industry & $\begin{array}{l}\text { The effect of insect feeds } \\
\text { on profitability and on } \\
\text { the sustainability of the } \\
\text { aquaculture industry. }\end{array}$ & $\begin{array}{l}\text { Will feed supplies become } \\
\text { more robust? }\end{array}$ & $\begin{array}{l}\text { Would the novel feed improve } \\
\text { the sustainability image of the } \\
\text { industry, and thereby improve } \\
\text { their dignity? }\end{array}$ & $\begin{array}{l}\text { Will insect feeds be allowed } \\
\text { by regulation? } \\
\text { Allow different marketing } \\
\text { strategies in the sector to } \\
\text { show who is really sustainable } \\
\text { and who is not. }\end{array}$ \\
\hline Retailers & $\begin{array}{l}\text { The effect on profitability. } \\
\text { A more diverse range of } \\
\text { products. }\end{array}$ & $\begin{array}{l}\text { Will there be negative } \\
\text { publicity? Will good labelling } \\
\text { prevent that? }\end{array}$ & $\begin{array}{l}\text { Will retailers have the choice } \\
\text { to include or not? }\end{array}$ & Fair trade conditions. \\
\hline Consumers & $\begin{array}{l}\text { Will insect salmon be more } \\
\text { nutritious and tastier? } \\
\text { Can insect salmon have } \\
\text { health benefits ('anti- } \\
\text { inflammatory food')? } \\
\text { (Participants did not believe in } \\
\text { that - healthy molecules such } \\
\text { as chitin seem to disappear in } \\
\text { the process.) }\end{array}$ & $\begin{array}{l}\text { Will insect feeds introduce } \\
\text { own health risks (malnutrition, } \\
\text { toxicity, zoonosis)? The } \\
\text { participants do not believe } \\
\text { in zoonosis because both } \\
\text { insects and fish are so } \\
\text { evolutionary distant from } \\
\text { humans. } \\
\text { Will insect feeds reduce } \\
\text { existing health risk concerns } \\
\text { with farmed salmon? } \\
\text { Negative experience (YUCK } \\
\text { factor). }\end{array}$ & $\begin{array}{l}\text { Will there be appropriate } \\
\text { labelling, choice and } \\
\text { transparent information? }\end{array}$ & $\begin{array}{l}\text { Availability and affordability of } \\
\text { the food. Will the availability } \\
\text { of insect feeds improve } \\
\text { national food security and } \\
\text { sovereignty? 'Regardless of } \\
\text { rhetoric, this is not about food } \\
\text { for the world, because } 50 \% \text { of } \\
\text { the feed is lost in the fjord.' }\end{array}$ \\
\hline Environment (fjord) & $\begin{array}{l}\text { Will increased tastiness } \\
\text { lead to less wasted fish feed } \\
\text { polluting the seafloor? } 50 \% \\
\text { goes to waste in current } \\
\text { practice, falls to the bottom. }\end{array}$ & $\begin{array}{l}\text { Novel feeds may help } \\
\text { increase the amount of } \\
\text { salmon farming. } \\
\text { The texture of the feed can } \\
\text { affect water quality, algae } \\
\text { growth and local pollution. }\end{array}$ & Biological diversity. & Sustainability (ecological). \\
\hline
\end{tabular}


Table 3. continued.

\begin{tabular}{|c|c|c|c|c|}
\hline \multirow[t]{2}{*}{ Entities to care for } & \multicolumn{4}{|l|}{ Respect for 4 ethical principles } \\
\hline & Beneficence & Non-maleficence & Autonomy & Justice as fairness \\
\hline $\begin{array}{l}\text { Environment (marine } \\
\text { ecosystem) }\end{array}$ & $\begin{array}{l}\text { Could kelp harvesting affect } \\
\text { eutrophication in sea areas? } \\
\text { (The participants did not } \\
\text { consider kelp a realistic } \\
\text { option.) }\end{array}$ & $\begin{array}{l}\text { Over-exploitation of kelp and } \\
\text { other substrates for insect } \\
\text { larvae. (The participants did } \\
\text { not consider kelp a realistic } \\
\text { option.) }\end{array}$ & Biological diversity. & Sustainability (ecological). \\
\hline $\begin{array}{l}\text { Environment (local and global } \\
\text { socio-ecological systems) }\end{array}$ & $\begin{array}{l}\text { Preservation; better use } \\
\text { of resources and waste } \\
\text { streams? Or is that } \\
\text { unrealistic? Can one produce } \\
\text { the insects locally, and avoid } \\
\text { transport? }\end{array}$ & $\begin{array}{l}\text { Pollution, risks of insect } \\
\text { escapes? } \\
\text { Over-exploitation? } \\
\text { greenwashing of the industry: } \\
\text { 'Perhaps the industry will } \\
\text { increase by } 500 \% \text {, with } 1 \% \\
\text { insect feed and the rest based } \\
\text { on soya.' } \\
\text { Shortage of feed/resources in } \\
\text { other sectors, e.g. if insects } \\
\text { are fed soy or potatoes. }\end{array}$ & Biological diversity. & $\begin{array}{l}\text { Cheap but not really } \\
\text { sustainable substrates (like } \\
\text { growing grains for insects } \\
\text { instead of using a waste } \\
\text { stream) should be avoided. }\end{array}$ \\
\hline Local community & Jobs, value creation. & $\begin{array}{l}\text { Conflicts with other industries, } \\
\text { area conflicts (also if growth } \\
\text { of aquaculture leads to land } \\
\text { production sites), pollution, } \\
\text { competition over feed } \\
\text { resources. }\end{array}$ & $\begin{array}{l}\text { The reputation of the } \\
\text { community and the possibility } \\
\text { to position oneself in terms } \\
\text { of feed choice ('the insect } \\
\text { village'). Undemocratic } \\
\text { processes of change in the } \\
\text { industries. }\end{array}$ & $\begin{array}{l}\text { Perception of fair handling } \\
\text { by authorities, including } \\
\text { taxation and fair distribution } \\
\text { of value creation to the local } \\
\text { community. }\end{array}$ \\
\hline Society, national level & $\begin{array}{l}\text { Jobs, value creation, proper } \\
\text { exploitation of biological } \\
\text { resources. }\end{array}$ & $\begin{array}{l}\text { Environmental risks, market } \\
\text { risks. (Norwegian economy } \\
\text { depends on this industry } \\
\text { going well.) }\end{array}$ & & \\
\hline
\end{tabular}

the insects with vegetable food waste from industries and retailers, will there be enough? And, from the perspective of sustainability, would it not be better to eat the insects rather than feeding them to fish? In this way, the ethical matrix exercise also became an opportunity to engage in a critical discussion of the sociotechnical imaginary of the project.

Finally, we constructed impact matrices during the workshops by asking the participants about the most important issues where the feed choice makes a difference. The feed choice was defined by the Aquafly PI, also because they matched with the salmon feeding experiment performed in the project Aquafly. The compositions did not distinguish between meal and oil:

- marine-based diet;

- plant-based diet;

- insect-marine based diet (50/50);

- insect-plant based diet (50/50).

The two workshops produced quite different results. Also, some participants argued that the choice of diets (and hence feeding practices) was not the important issue, but rather that more types of feed would increase the flexibility and availability of feed supply. Aggregated results are presented in Table 4.

A first observation was that some of the relevant concerns were already addressed by the research in Aquafly, in particular issues of feed safety, contaminants and nutrient content. Fish welfare was also observed during the salmon feeding experiments.

For a number of other concerns, there was an expectation of the type of impact or even the sign of the impact; while for other concerns, no indicator was conceived, or the issue was seen as indeterminate because the scenario itself was indeterminate. For instance, concerns for area use, efficient use of waste streams, reputation risks, etc., were seen to depend not only on the choice of feed but by the larger socio-technical solutions that the choice was imagined to be a part of.

As noted above, the two workshops produced rather different results. Ethical Matrix workshops should not be seen as a method to produce unique and 'objective' answers to a given set of question. Rather, their use is to 
Table 4. Impact matrix for AquaFly.

\begin{tabular}{|c|c|c|c|c|c|}
\hline \multirow[t]{2}{*}{ Entities to care for } & \multirow[t]{2}{*}{ Concerns } & \multicolumn{4}{|l|}{ Narratives (scenarios) } \\
\hline & & Marine-based diet & Plant-based diet & $\begin{array}{l}\text { Insect-marine based } \\
\operatorname{diet}(50 / 50)\end{array}$ & $\begin{array}{l}\text { Insect-plant based diet } \\
(50 / 50)\end{array}$ \\
\hline \multirow[t]{4}{*}{ Animals } & Feed safety & $\begin{array}{l}\text { Heavy metals, dioxins, } \\
\text { DDT, PCBs }\end{array}$ & Pesticides, mycotoxins & $\begin{array}{l}\text { As with marine, but less? } \\
\text { Unknown toxins? }\end{array}$ & $\begin{array}{l}\text { As with plant, but less? } \\
\text { Unknown toxins? }\end{array}$ \\
\hline & $\begin{array}{l}\text { Water quality for salmon: } \\
\text { Indicator is turbidity }\end{array}$ & & & \multicolumn{2}{|c|}{ Perhaps better because of higher chitin content? } \\
\hline & $\begin{array}{l}\text { Fish health: Indicators } \\
\text { are feed uptake, lack of } \\
\text { production disorders, } \\
\text { behaviour }\end{array}$ & \multicolumn{4}{|c|}{ To be observed. So far no effect seen. Plant-based diets apparently are better to avoid salmon lice. } \\
\hline & Welfare of feed & $\begin{array}{l}\text { Animal welfare in } \\
\text { fisheries }\end{array}$ & - & Insect stress & Insect stress \\
\hline \multirow[t]{4}{*}{$\begin{array}{l}\text { Producers, } \\
\text { Industry }\end{array}$} & Reputation risks & & & \multicolumn{2}{|c|}{$\begin{array}{l}\text { Unforeseen problems? } \\
\text { Reputation risks with increased product } \\
\text { differentiation }\end{array}$} \\
\hline & $\begin{array}{l}\text { Feed availability and } \\
\text { flexibility }\end{array}$ & Poor & & \multicolumn{2}{|l|}{ Perhaps better? } \\
\hline & Feed costs & Twice the price of soy & & \multicolumn{2}{|c|}{$\begin{array}{l}\text { Participants guess that insect meal will be twice the } \\
\text { price of fish meal }\end{array}$} \\
\hline & Product quality & & & & \\
\hline \multirow[t]{3}{*}{ Consumers } & $\begin{array}{l}\text { Nutrient content } \\
\text { (omega-3, B12, Vit D, } \\
\text { iodine) }\end{array}$ & ++ & - & + & - \\
\hline & Toxins, contaminants & $\begin{array}{l}\text { Heavy metals, dioxins, } \\
\text { DDT, PCBs }\end{array}$ & Pesticides, mycotoxins & $\begin{array}{l}\text { As with marine, but less? } \\
\text { Insects can accumulate } \\
\text { heavy metals. } \\
\text { Unknown toxins? }\end{array}$ & $\begin{array}{l}\text { As with plant, but less? } \\
\text { Insects can accumulate } \\
\text { heavy metals. } \\
\text { Unknown toxins? }\end{array}$ \\
\hline & Global food availability & & & \multicolumn{2}{|c|}{$\begin{array}{l}\text { Will increased feed availability increase salmon } \\
\text { aquaculture to unsustainable levels? }\end{array}$} \\
\hline \multirow[t]{5}{*}{ Environment } & $\begin{array}{l}\text { Pollution in fjords below } \\
\text { netpens }\end{array}$ & & & & \\
\hline & $\begin{array}{l}\text { Efficiency of feed } \\
\text { production }\end{array}$ & & & \multirow{4}{*}{\multicolumn{2}{|c|}{$\begin{array}{l}\text { The workshop discussions indicated that the } \\
\text { scenarios have indeterminate impacts unless } \\
\text { they are combined with the richer sociotechnical } \\
\text { imaginaries. For instance, the transportation needs, } \\
\text { the feed security, the area use, the efficient use of } \\
\text { waste streams, local autonomy all depend on what } \\
\text { the insects will be fed, and where they are going to } \\
\text { be produced. }\end{array}$}} \\
\hline & $\begin{array}{l}\text { Efficient use of waste } \\
\text { streams }\end{array}$ & & & & \\
\hline & Area use & & High & & \\
\hline & $\begin{array}{l}\text { Transportation needs } \\
\text { for feed }\end{array}$ & & High & & \\
\hline \multirow[t]{2}{*}{ Local community } & Value creation, jobs & & & & \\
\hline & Local autonomy & & & & \\
\hline \multirow[t]{2}{*}{ Society } & Robust feed security & & & & \\
\hline & $\begin{array}{l}\text { Reputation of Norwegian } \\
\text { salmon aquaculture }\end{array}$ & & & & \\
\hline
\end{tabular}


map and explore values and concerns as they are expressed in a group of deliberating individuals, subject to the same limitations as all methods of this type with respect to limited reproducibility, and a degree of arbitrariness with respect to minority views and infrequent views. Furthermore, the role of the moderator in explicating and shaping the entries in the tables is not trivial, in particular with the less intuitive steps such as the translation of concerns into impacts of decision choices.

\section{Quantitative story-telling through the application of MUSIASEM}

The insights obtained by adopting the QST approach that are discussed are based on the quantitative results presented in another paper (Cadillo-Benalcazar et al., 2020), in which the approach Multi-Scale Integrated Assessment of Societal and Ecosystem Metabolism (MuSIASEM) has been used to characterise the performance of different technological solutions for the production of salmon. One of the relevant features of the MuSIASEM approach used in that paper is that it makes it possible to generate an information space based on different sets of indicators of performance reflecting different pre-analytical choices about: (1) the framing of targets (linked to goals and concerns); (2) the dimensions of analysis (economic, social, ecological, technological); (3) the level of analysis (household, community, local ecosystem, the country, the global atmosphere).

The results of a multicriteria analysis of the performance of different technological options for producing salmon (HOW to do the WHAT) can be used as a starting point for a reflection about the WHY are we producing salmon (the chosen WHAT to do) in the first place. This discussion can be framed within a historic analysis of the WHAT - the production of salmon in Norway.

The production of salmon keeps growing and we know that the scaling up of any economic activity unavoidably implies pros and cons. Looking at the indicators of performance of salmon production we can clearly see that a dramatic increase in production is associated with an analogous increase in: (1) environmental impact; and (2) economic resources to be invested in the activity. Given the limitedness of any system of production - Norway has given boundaries - a large increase in the size of the operation (both producing and eating salmon) can only be obtained by boosting the 'crossing of the physical borders' of flows. Both imports (required for the production of salmon) and exports (required for obtaining revenues from the activity) have been steadily growing since the onset of aquaculture production in Norway. From a production perspective, the change in the level of externalisation has had significant consequences on the quality of feed: In the 1990s the feed contained $90 \%$ of ingredients from marine origins but in recent years this percentage has dropped to nearly 30\% (Ytrestøyl et al., 2015). This move can be easily explained by the clear saturation of the productivity of marine fisheries that has reached a peak in terms of total production and that is showing clear signs of decreasing marginal returns (FAO, 2017) plus the volatility of the availability and pricing of the most used marine fish, the Peruvian anchoveta, due to natural El Niño weather events (Chavez et al., 2003; Cushing, 1981) which can be further aggravated by anthropogenic climate change (Chavez et al., 2003).

The change from marine ingredients to the massive use of land-based feed ingredients in Norwegian salmon feed has implied a dramatic externalisation of the requirements of inputs in the process of producing feed ingredients. The results of the analysis of Cadillo-Benalcazar et al. (2020) indicate that the majority of the hours of labour (66\%) for the whole salmon production process are now required only for the production of land-based feed ingredients. Moreover, the production of land-based feed ingredients also requires huge quantities of fresh water evapotraspirated in the agricultural production phase. It should be noted, however, that this process of externalisation of factors of productions is associated with a positive economic feedback. The gross revenues of salmon sales are five times larger than the costs to be paid for importing the inputs. According to an economic narrative it would be reasonable for Norway to keep doing more of the same.

When considering other narratives we can clearly see also negative aspects of the 'more of the same' option. The externalisation of feed ingredients production has serious consequences on other social-ecological systems. The results of the analysis of Cadillo-Benalcazar et al. confirm the concern expressed by Torrisen et al. (2011) about the negative side effects: increasing crop production for animal feeds is associated with deforestation in South America (leading to soil erosion) and a resulting environmental impact of fertilisers and pesticides. A massive use of crops (that could be used for human consumption) for feeding salmon would compete with land required for food security. In this way, salmon production will become analogous to the intensive production of meat in beef-lots. Not only does the production of feed for animals compete for land, but also for labour that is no longer available for producing cheap staple food for local populations.

For this reason, in the field of salmon production there is an important effort aimed at developing new technical solutions capable of fulfilling the most ancient dream of humankind: 'how to have your cake and eat it too'. In our case this dream should be translated into 'how to get dramatic increase in the volume of produced salmon while consuming less resources and generating less environmental impact.' This is where the idea of using insects as ingredients 
of the diet enters into play. The idea has merit because it implies adding a new element to the metabolic pathway enabling more options. That is, from the conventional way of producing salmons with marine ingredients (A) we can move to a production of salmon that can be based on a much larger set of potential ingredients (B):
A. 'feed source, $\rightarrow$ salmon;
B. 'feed source, $\rightarrow$ insect $\rightarrow$ salmon

In fact, salmon can only eat a limited set of feed sources (the set is limited), whereas a variety of different insects can eat a huge variety of feed sources (the set of possible sources is much larger). Given this new possibility provided by the inclusion of insect in the supply system of feed ingredients, what should be discussed to evaluate the pros and cons of this option?

By adopting the rationale of QST, we start from the WHY question.

\section{WHY is Norway producing salmon in the first place?}

The answer 'to guarantee the food security to the Norwegian people' is obviously not pertinent, because the actual production of salmon exceeds already by far the local consumption ${ }^{2}$. This answer would not justify any effort toward additional production. Another answer based on an economic narrative could be in order to be able to generate more added value.' This answer cannot be accepted per se as a justification narrative. Other criteria should also be considered when deciding how to generate added value.

For this reason, if we try to define the final cause of salmon production (the WHY that should be used in the justification narrative to decide WHAT to do) we have to start with a definition based on semantic statements that have to be transformed into practical policies (the specification of WHAT should be done) through a process of reflection and deliberation. For example we can agree that the final cause of salmon production should be to give a desirable welfare to the people while trying to avoid negative impacts on ecosystems and other people living in distant countries'. If we accept this 'generic' definition, its

\footnotetext{
${ }^{2}$ Total salmon production in 2017 was 1.2 million tonnes (Statistics Norway), while the average seafood consumption (which includes all types of seafood, not only salmon) was 20.5 kilograms (0.025 tonnes) per capita in 2016 (https://www.statista.com/statistics/643484/percapita-consumption-of-fish-and-fish-products-in-norway/) by a population of roughly 5.2 million people. Therefore the national salmon production exceeds 11 times the amount necessary for food security in Norway. This simple calculation underlines the well-known local fact in Norway that salmon production is a global commodity, not a locally-limited product.
}

practical use in a process of decision-making is contingent on the interpretation of the terms 'desirable welfare' and 'trying to avoid negative impacts on ecosystems and other people living in distant countries'. If we try to associate practical meaning to these terms we immediately realise that the economic narrative is not particularly useful for this task. What if maximising profit does imply economies of scale, large investments that can only be done by large corporations, the requirement of cheap inputs? What if maximising profits does not guarantee that the larger revenues remain in the communities of fishermen or in the communities where the production of salmon is taking place? What if maximising profits implies an unavoidable externalisation of stress to other ecosystems and economically weaker societies? What if maximising the profit does not guarantee a desirable welfare for the majority of the people?

These type of reflections are avoided when adopting the story-telling of the 'economies of technological promises' - i.e. 'do not worry about these doubts, all these problems will be avoided or solved by technological innovations'. In relation to salmon production we can add an additional metabolic element in the system - adding insects between the source of feed ingredients and the salmon - so that we can expand the option space in which technological innovations can operate and for sure we will be able to have the cake and eat it too ${ }^{3}$. In relation to this promise, a known motif in socio-technical imagination is 'the next generation of an existing technology'. Every time a given technology arrives to an end point and it is no longer delivering on its promises, 'the next generation' label arrives to save the situation as the $7^{\text {th }}$ cavalry in old western movies. In the field of salmon production the next generation seems to get the name of 'novel feeds' such as insect-based diets. The use of insects in salmon production is framed within the grand narrative of the 'circular economy' - insects can feed on waste and sewage and therefore they are perfect to close the loop of material flows. However, whilst adding an additional element to a food chain may have some benefits - because it solves some identified problems, it may also become problematic because it brings with it a lot of new and unexpected problems. Insects are alive and among the most adaptive living beings with whom humans are sharing the planet. Previous experiences tell us that food chains are complex and full of surprises (bio-accumulation, mad cow disease; see European Environment Agency, 2001).

If we decide to discard the story-telling of the 'economy of technological promises' - 'yes we can control nature

\footnotetext{
${ }^{3}$ The idiom of 'having your cake and eating it too' also rears its head in the local Norwegian oil extraction and climate debate, see here: https://youngscientistforum.wordpress.com/2017/11/28/can-wehave-our-cake-and-eat-it-too/
} 
and expand our activities at our will' - we can consider an alternative story-telling based on the acceptance of our responsibility as reflexive agents living on a planet in which the resources are limited in the face of a population that is still expanding. Rather, the new story-telling should be 'Houston we have a problem: the run-away train of economic growth has led us, in many cases, to overshoot the carrying capacity of the planet.' Within this new story-telling we should still consider all the possible innovations that can become beneficial for socio-ecological systems. However, it is important to check the quality of the information (both in relation to the pre-analytical choice of narratives and the analytical choice of quantitative analysis) used in the process of deliberation.

\section{Discussion}

Above, we have displayed two distinct but complementary attempts to introduce responsibility, in the sense of anticipation and reflexivity, into the Aquafly research project. The Ethical Matrix approach tries to elicit and explicate concerns, dilemmas, knowledge gaps and needs, uncertainties and codependencies 'as conceived within the research consortium' The QST approach performs an external critique of the imaginaries surrounding the project by holding them accountable to questions of 'why?' and of feasibility and viability. They show the relationship between the quite necessary production of sociotechnical imaginaries that justify and give direction to the project, with larger narratives of the economies of technological promises, and suggest that this relationship in itself poses a threat to sustainability.

For us as authors of this study, it is interesting to reflect upon our initial expectations for how to combine the Ethical Matrix with QST. In a previous study (Giampietro and Bukkens, 2015) the two approaches were combined in an elegant way. That paper provided an example in which the analysis of a given policy was carried out combining: (1) an impact matrix - consisting of a series of different indicators of performance describing the expected effects of a given policy in relation to different criteria; (2) an equity matrix - consisting of an analysis of the various perceptions of the specific set of social actors affecting/affected the given policy, checking whether they feel that they are winners, losers or neutrally affected by it; and (3) an ethical matrix in which a standard compilation of ethical issues is used to elicite the visualisation of the concerns of social actors about the expected consequences of the policy on the entities they care for. A triangulation among these three matrices allows us to study: (1) whether the scientific information used to inform the decision process (the impact matrix) covers the various concerns of the different actors; (2) the response of the social actors to the set of proposed policies (the equity matrix). This matrix is relevant when discussing the possible implementation of policies; (3) the narratives and attributes the social actors use to visualise the consequences of a set of proposed policies when considering their effect on the entities they care for. In particular, the link between the ethical matrix (concerns to be addressed) and impact matrix (indicators of performance that are available) can be used to flag missing indicators or missing perspectives in the scientific representations used to inform policy. In relation to this problem, the MuSIASEM approach allows to generate indicators 'à la carte' starting from a holistic analysis of the relations over different aspects of the issue that can be observed at different scales using different dimensions (integrating non-equivalent narratives). In Aquafly, we tried the same approach but failed, in the sense that there was little overlap between the concrete concerns suggested by the ethical-environmental impact matrix and the indicators that MuSIASEM were able to produce. Three noteworthy observations can be made in this regard. First, several of the concerns in the impact matrix were actually addressed by the Aquafly project itself, in particular those of salmon and human consumers (feed safety, fish health, nutrient contents, toxins and contaminants). Indeed, scientific research into those concerns was an essential part of the project. Secondly, in the study cited above (Giampietro and Bukkens, 2015) the ethical matrix was made by the authors themselves, meaning that the same persons were the source of the entries in the Ethical Matrix and the framing of the MuSIASEM exercise. The partial lack of congruence in the Aquafly case may to some degree be explained by less emphasis on sustainability in terms of socio-ecological metabolism in the Aquafly consortium. If so, that is a finding in itself. Still, however, it is right to say there were extensive discussions on the global issues of sustainability in the Ethical Matrix workshops. The third observation is one already made in Table 4 above:

The workshop discussions indicated that the scenarios have indeterminate impacts unless they are combined with the richer sociotechnical imaginaries. For instance, the transportation needs, the feed security, the area use, the efficient use of waste streams, local autonomy all depend on what the insects will be fed, and where they are going to be produced.

In other words, as long as the sociotechnical solution still is in the making, its impacts appear as indeterminate. This is not to say, with the Collingridge dilemma, that they are unthinkable and unpredictable. They appeared, however, not sufficiently fixed and tangible to allow meaningful quantification.

From the QST perspective, such a process of science-inthe-making may be deemed irresponsible in the sense of RRI, because it effectively pushes possible global impacts of the technology to be made, into the future ('the next generation of technology', or a future exercise of impact assessment) and/or into ignorance. This effectively means 
that while one is creating a technology - a solution to a question of 'how' - that happens at the expense of the 'why' in terms of final causes or purposes and ultimately 'what' in terms of social and political choices. From the internal perspective of such a research project, however, its first responsibility was to try to create the scientific and technical results that it has promised, or rather projected. The contract with the funder specifies that a solution to the question of how should be found, and the task at hand is to somehow develop a trajectory that leads to that how.

As mentioned in the introduction, the research process of Aquafly, a mere instance among many others, has to employ scientific, technical and social creativity and imagination producing what we have called sociotechnical imaginaries - to find a way through all the initial uncertainties, indeterminacies and degrees of freedom. However, the process is even more an encounter with the material world and its agency, as when the kelp flies resist to be produced in massive amounts, or the black soldier flies don't thrive on kelp only. It is immensely difficult to stabilise the technical solution because of the many unpredictable responses from the natural world. Although Aquafly cannot be called curiosity-driven science, the research process still resembles what Rheinberger (1997) called the 'making of epistemic things': From the initial uncertainty and indeterminacy, the research trajectory zig-zags towards a stable set of signals from a stable experimental system. As the knowledge becomes less tentative and more reliable, one becomes entitled to claim that one has a well-defined system; and at the same time, as the system becomes less tentative and more well-defined, one may claim to have reliable knowledge.

The ambition of RRI is to introduce more constraints into the middle of such a process, by demanding not only that the trajectory takes shape but also finds a direction towards socially desirable goals. Aquafly itself took on the responsibility to do so in terms of feed safety, nutrient contents and toxicity, as a matter of design.

From the food ethics perspective, one may hope and work for a continued shaping of the research trajectory towards sustainability. This could be realised if the project results are followed up by translational research to upscale insect feed production for salmon and develop technical solutions for the many aspects of upscaling: logistics, business models, political and corporate will and the like. One could then make another iteration of the QST and Ethical Matrix methodologies, now applying QST to the aspects that were indeterminate when the technology was at its lowest level of technological readiness, and trying to shape it actively towards sustainability in terms of socioecological metabolism. In an RRI fashion, one would then also include more stakeholders and other societal actors into the elicitation of Ethical Matrices in order to have more concerns mapped and voiced. We believe such a process could be meaningful and we recommend it.

However, one should be aware of the risk that the 'Aquafly dream' of a sustainable circular economy of insect-filled salmon feed could fail. There is, of course, a chance that the resolution of technical challenges (and in that step, also economic challenges) might appear so demanding that 'extra concerns' such as sustainability once again are sidetracked or pushed forward in time. If so, a moment of reflexivity is called for also for practitioners such as the authors of this study, asking the self-critical question: 'Do we make a difference or are our methods mainly greasing the wheels of the economies of technological promises?'

So far, RRI efforts have - in a deep irony - focused a lot on the 'how' at the frequent expense of the 'why', also in this case because the how poses its own difficulties. The 'why' is not intractable, however, and the following long-term RRI research question can be posed: In what kind of research projects, and under what conditions, can RRI methods such as the Ethical Matrix and QST actually make a difference? Which kinds of research undertakings, under which conditions, seem simply to be unable of responsiveness? This is an empirical question and a very important one: Unless it is pursued, we run the risk of doing little more than greenwashing, even of blue biotechnologies such as salmon aquaculture. In the case of Aquafly, we cannot claim to have firm evidence of change in research trajectory due to the RRI efforts within the lifetime of the project. There is even a tension in design when research projects are funded for a relatively short time period (three years in the case of Aquafly) and with a very detailed contract and work plan, and at the same time contain an open-ended element such as RRI. The empirical question should be studied from a long-term perspective, however, to see if research practice changes over time. One has to be prepared for significant problems of attribution when investigating that empirical question. RRI, Ethical Matrix and QST are no more silver bullets or technical fixes than 'real' technologies and should not be thought of as a social engineering type of product within the economy of technological promises. However, achievements may be noted. This paper - a scholarly RRI paper - is now being published in the Journal of Insects for Food and Feed. What difference may that make in the long run?

\section{Acknowledgements}

We are most grateful to the PI and the participants of the Aquafly Team for collaboration, comments on this manuscript and for warmly including us in their research endeavour. The authors also gratefully acknowledge funding from the Research Council of Norway under grant agreement 238997/E40 (Insects as natural feed ingredients for sustainable salmon farming - AQUAFLY). Authors GG 
and MG acknowledge financial support from the Spanish Ministry of Science and Innovation (MICINN) through the 'María de Maeztu' program for Units of Excellence (CEX2019-000940-M).

\section{Conflict of interest}

The authors declare no conflict of interest.

\section{References}

Beauchamp, T.L. and Childress, J.F., 1979. Principles of biomedical ethics. Oxford University Press, Oxford, UK.

Belghit, I., Liland, N.S., Gjesdal, P., Biancarosa, I., Menchetti, E., Li, Y., Waagbø, R., Krogdahl, Å. and Lock, E.J., 2019. Black soldier fly larvae meal can replace fish meal in diets of sea-water phase atlantic salmon (Salmo salar). Aquaculture 503: 609-619. https:// doi.org/10.1016/j.aquaculture.2018.12.032.

Bremer, S., Millar, K., Wright, N. and Kaiser, M., 2015. Responsible techno-innovation in aquaculture: employing ethical engagement to explore attitudes to GM salmon in northern Europe. Aquaculture 437: 370-381. https://doi.org/10.1016/j.aquaculture.2014.12.031

Cadillo-Benalcazar, J.J., Giampietro, M., Bukkens, S.G.F. and Strand, R., 2020. Multi-scale integrated evaluation of the sustainability of large-scale use of alternative feeds in salmon aquaculture. Journal of Cleaner Production 248: 119210. https://doi.org/10.1016/j. jclepro.2019.119210

Chavez, F.P., Ryan, J., Lluch-Cota, S.E. and Niquen C, M., 2003. From anchovies to sardines and back: multidecadal change in the pacific ocean. Science 299(5604): 217-221. https://doi.org/10.1126/ science. 1075880

Collingridge, D., 1980. The social control of technology. St. Martin's Press, New York, NY, USA.

Cushing, D.H., 1981. The effect of El Niño upon the Peruvian anchoveta stock. In: Richards, F.A. (eds.) Coastal upwelling. American Geophysical Union (AGU), Washington, DC, USA, pp. 449-457.

Diener, S., Zurbrügg, C., Roa-Gutiérrez, F., Hong Dang, N., Koottatep, T., Tockner, K. and Morel, A., 2011. Black soldier fly larvae for organic waste treatment - prospects and constraints. In: WasteSafe 2011, $2^{\text {nd }}$ International Conference on Solid Waste Management in Developing Countries. 13-15 February 2011. Khulna, Bangladesh.

Diener, S., Zurbrügg, C. and Tockner, K., 2009. Conversion of organic material by black soldier fly larvae: establishing optimal feeding rates. Waste Management \& Research 27: 603-610. https://doi. org $/ 10.1177 / 0734242 X 09103838$

European Environment Agency, 2001. Late lessons from early warnings: the precautionary principle 1896-2000. Environmental Issue Report 22. EEA, Copenhagen, Denmark. Available at: https://www.eea. europa.eu/publications/environmental_issue_report_2001_22/ Issue_Report_No_22.pdf/view

Food and Agriculture Organisation (FAO), 2013. Fishery and aquaculture country profiles - the Kingdom of Norway. FAO, Rome, Italy. Availablea at: http://www.fao.org/fishery/facp/NOR/en
Food and Agriculture Organisation (FAO), 2017. Technical conversion factors for agricultural commodities. FAO, Rome, Italy. Available at: http://www.fao.org/fileadmin/templates/ess/documents/ methodology/tcf.pdf

Food and Agriculture Organisation (FAO), 2018. The state of world fisheries and aquaculture 2018: meeting the sustainable development goals. FAO, Rome, Italy. Available at: http://www. fao.org/documents/card/en/c/I9540EN/

Gasco, L., Gai, F., Maricchiolo, G., Genovese, L., Ragonese, S., Bottari, T. and Caruso, G., 2018. Feeds for the aquaculture sector: current situation and alternative sources. Chemistry of foods. Springer International Publishing, Cham, Switzerland.

Giampietro, M. and Bukkens, S.G.F., 2015. Quality assurance of knowledge claims in governance for sustainability: transcending the duality of passion vs. reason. International Journal of Sustainable Development 18(4): 282-309.

Grinbaum, A. and Dupuy, J.P., 2004. Living with uncertainty: toward the ongoing normative assessment of nanotechnology. Techné: Research in Philosophy and Technology 8: 4-25. https://doi.org/10.5840/ techne2004822

Henry, L.M., Maiden, M.C.J., Ferrari, J. and Godfray, H.C.J., 2015. Insect life history and the evolution of bacterial mutualism. Ecology Letters 18(6): 516-525. https://doi.org/10.1111/ele.12425

Jasanoff, S. and Kim, S.H., 2009. Containing the atom: sociotechnical imaginaries and nuclear power in the United States and South Korea. Minerva 47(2): 119. https://doi.org/10.1007/s11024-009-9124-4.

Kaiser, M. and Forsberg, E.M., 2001. Assessing fisheries using an ethical matrix in a participatory process. Journal of Agricultural and Environmental Ethics 14(2): 191-200. https:// doi.org/10.1023/A:1011300811590

Latour, B., 1987. Science in action: how to follow scientists and engineers through society. Harvard University Press, Cambridge, MA, USA.

Liland, N.S., Biancarosa, I., Araujo, P., Biemans, D., Bruckner, C.G., Waagbø, R., Torstensen, B.E. and Lock., E.J., 2017. Modulation of nutrient composition of black soldier fly (Hermetia illucens) larvae by feeding seaweed-enriched media. PLoS ONE 12(8): e0183188. https://doi.org/10.1371/journal.pone.0183188

Makkar, H.P.S., Tran, G., Heuzé, V. and Ankers, P., 2014. Stateof-the-art on use of insects as animal feed. Animal Feed Science and Technology 197: 1-33. https://doi.org/10.1016/j. anifeedsci.2014.07.008

Pereira, A.G. and Funtowicz, S., 2015. Science, philosophy and sustainability: the end of the cartesian dream. Routledge, London, UK.

Pickering, A., 1995. The mangle of practice: time, agency, and science. University of Chicago Press, Chicago, IL, USA.

Rheinberger, H.-J., 1997. Toward a history of epistemic things: synthesizing proteins in the test tube, $1^{\text {st }}$ edition. Stanford University Press, Stanford, CA, USA.

Rip, A., 2018. Constructive technology assessment. Futures of science and technology in society. Springer, Wiesbaden, Germany, pp. 97-114. 
Saltelli, A. and Giampietro, M., 2017. What is wrong with evidence based policy, and how can it be improved? Futures, PostNormal Science in Practice 91: 62-71. https://doi.org/10.1016/j. futures.2016.11.012

Stilgoe, J., Owen, R. and Macnaghten, P., 2013. Developing a framework for responsible innovation. Research Policy 42(9): 1568-1580. https://doi.org/10.1016/j.respol.2013.05.008

Torrissen, O., Olsen, R.E., Toresen, R., Hemre, G.I., Tacon, A.G.J., Asche, F., Hardy, R.W. and Lall, S., 2011. Atlantic salmon (Salmo salar): the 'super-chicken' of the sea?' Reviews in Fisheries Science 19(3): 257-278. https://doi.org/10.1080/10641262.2011.597890
Von Schomberg, R., 2011. Towards responsible research and innovation in the information and communication technologies and security technologies fields. Publications Office of the EU, Luxembourg. Available at: https://data.europa.eu/doi/10.2777/58723

Wynne, B., 1992. Misunderstood misunderstanding: social identities and public uptake of science. Public Understanding of Science 1(3): 281-304. https://journals.sagepub.com/doi/10.1088/0963$6625 / 1 / 3 / 004$

Ytrestøyl, T., Aas, T.S. and Åsgård, T., 2015. Utilisation of feed resources in production of atlantic salmon (Salmo salar) in Norway. Aquaculture 448: 365-374. https://doi.org/10.1016/j. aquaculture.2015.06.023 